\author{
Military Technical College \\ Kobry El-Kobbah, \\ Cairo, Egypt
}

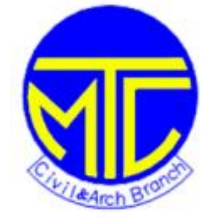

\title{
Thematic visualization of built environment using microclimatic coupled mapping methodology to support urban neigbourhood design
}

\author{
Amr Elwan ${ }^{1,2}$, Mohammad Fahmy ${ }^{2}$ and Chengzhi Peng ${ }^{1}$
}

\begin{abstract}
:
In order to understand the relation between urban neigbourhood design and its effects on microclimate, two experimental software cycles have been applied to a newly designed urban site in Cairo. These cycles were applied for outdoor -indoor microclimate meteorology generation; also a 3D web based modelling method was used to increase the awareness in the Egyptian research society about the importance and benefits of climate based ur ban design. The first cycle was shown by visualizing meteorological output data. The concluded thematic maps were then plotted on the 3D models in the second cycle. Results in terms of 3D meteorological mapped perspectives of the selected site show a stron $\mathrm{g}$ relation between outdoor and indoor conditions for architects and urban planners who may not normally deal with the many interdisciplinary field of urban climate. However, these results show that climate based modelling using CAAD can become an informati ve process specifically to support sustainable design and climate change awareness. It also proves the effectiveness of adopting passive design options such as green roads in urban neighborhood design.
\end{abstract}

Keywords: Thematic visualization, coupled mapping, o utdoor-indoor meteorology coupling, climate based CAAD, climate change, green roads.

\section{Introduction}

Urban climatology is an interdisciplinary field rel evant to urban form design. Its complexities prevented applying climate knowledge within urban planning process and practice (Oke 1984; Eliasson 2000; Ali-Toudert, Djenane et al. 2005; Oke 2006; Ali-Toudert and Mayer 2007b; Fahmy and Sharples 2008b; Fahmy 2010a). Designing urban form has to consider climate that affects the thermal performance of outdoor spaces and in turn pedestrian comfort, indoor energy consumption and climate change as a guide for future urban developments. It can be also argued that predicting the thermal performance of future urban forms "doesn't exist completely on the ground of climate change literature and its related consequences until now"(Fahmy 2010a). Therefore, urban thermal comfort will become an increasingly important issue. This paper reports on an experimental design of urban form by generating and comparing among different design alternatives. Visualization of urb an meteorological factors is technically challenging as it involves thermodynamics, heat transfer physics, and

1

2

Department of Architecture, Military Technical College, Cairo, Egypt 
human physiology principles used in describing urban environment. There are several $\mathrm{u}$ rban microclimate models due to the different physical bas es, temporal and spatial resolution s. The most well founded 3D microclimate models are wind flow models whereas those including hydrothermal and energy processes are very few.

Among these later models, ENVI-met (Bruse 2010), has approved validity and reliability to some extent to describe all outdoor built environment interactions depending on numerical calculations and 3D finite difference to ease these calculations. In contrast, CAD-based models attempt to generate the 3D urban scene parallel with an urban heat budget calculation which is too hard until now and cannot be compared for example with ENVI -met outputs (Asawa, Hoyano et al. 2008). Some simplified ways present environmental factors on a physical model led to the Digital Elevation Model (DEM) such as reported by Ratti and coworkers, (Ratti, Raydan et al. 2003), which is a 2D thematic mapping for urban environment factors. Human brain realizes efficiently with perception and ext racts a lot of data from a scene. So before data extraction, visualization might help the users to better understand the data. Virtual model is one of the key points in the architectural practice and way of thinking because it allows the users to easily pe rceive and understand the data and to directly interact with them. From these standing points, complexity of using urban climate knowledge can be overcome by processing climate studies visual outputs on a web accessible 3D virtual modeling platform called uCampus,(Peng et al 2010). Consequently, the 3D MAX virtual models used to present environmental simulated factors from a prior software cycl e can be accessed by more easily designers and provided a connection between outdoor and indoor environment.

\section{Case study description}

Due to the expected large area of a selected case study, field work including measurements is not a suitable method of asse ssment for the existing situation. Specially, the simulation process will be repeated many times with different conditions. The selected Case study is in a new compound development at the east of the existing old city in Cairo. The new development is an ongoing project held by DAMAK Company (Fig.1). The master plan contains repeated prototypes which consist of 3 floors. Four single semidetached building units in different locations in the neighbourhood were chosen, (Table1).

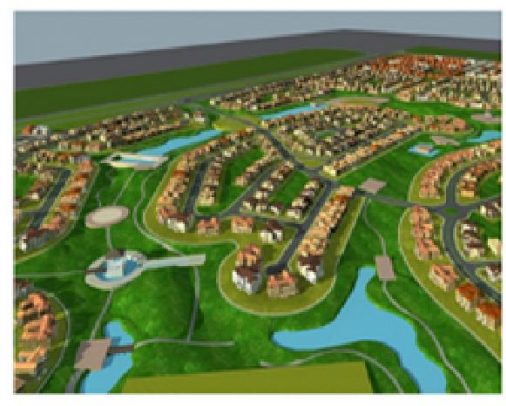

3 model of the case study by $3 D M A X$

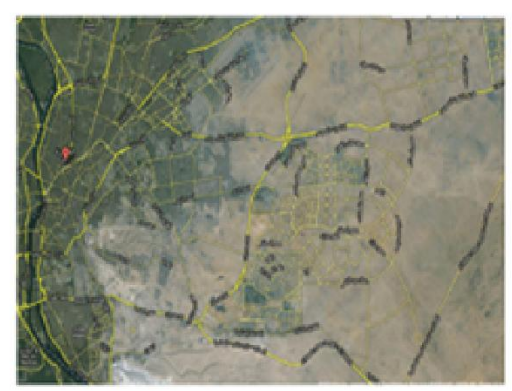

Map of new Cairo in the east of existing old city

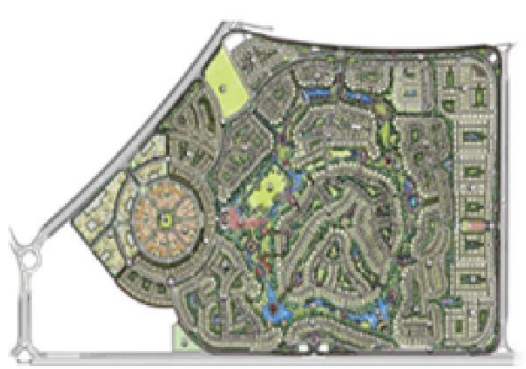

Locations of the chosen neighbourhood

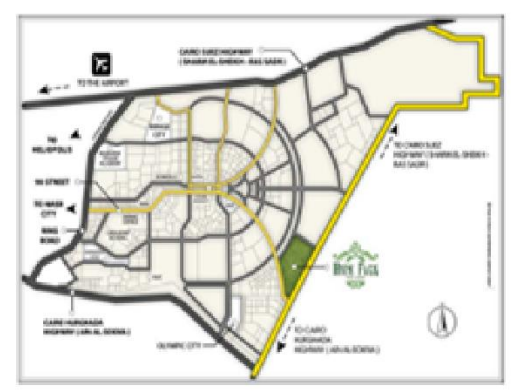

The location of Case study and airport 
Table Fig. 1. Illustration for the case study location in Cairo.

\begin{tabular}{|c|c|c|}
\hline Parameter & Detailed model $(1,2)$ & Detailed model $(3,4)$ \\
\hline Total area & $540 \mathrm{~m} 2$ & $500 \mathrm{~m} 2$ \\
\hline No. of floor & 3 floors & 3 floors \\
\hline Ext. walls & $\begin{array}{l}0.25 \mathrm{~m} \text { brick } 20 \mathrm{~mm} \text { plaster inside and } \\
\text { outside }\end{array}$ & $0.25 \mathrm{~m}$ brick $20 \mathrm{~mm}$ plaster inside and outside \\
\hline Int.walls & $\begin{array}{l}0.25 \mathrm{~m} \text { brick } 20 \mathrm{~mm} \text { plaster inside and } \\
\text { outside }\end{array}$ & $0.25 \mathrm{~m}$ brick $20 \mathrm{~mm}$ plaster inside and outside \\
\hline $\begin{array}{l}\text { Floor } \\
\text { height }\end{array}$ & $3.2 \mathrm{~m}$ & $3.2 \mathrm{~m}$ \\
\hline Orientation & North to south & East to west \\
\hline Roof & $\begin{array}{l}20 \text { tiles } 20 \text { mortar } 50 \text { sand } 150 \mathrm{~mm} \\
\text { concert }\end{array}$ & $\begin{array}{l}20 \text { tiles } 20 \text { mortar } 50 \text { sand } 150 \mathrm{~mm} \\
\text { concert }\end{array}$ \\
\hline Glazing & $6 \mathrm{~mm}$ single glass & $6 \mathrm{~mm}$ single glass \\
\hline $\begin{array}{l}\text { Thermal } \\
\text { zones }\end{array}$ & Multi zones & Multi zones \\
\hline lighting & $12 \mathrm{w} / \mathrm{m} 2$ & $12 \mathrm{w} / \mathrm{m} 2$ \\
\hline occupancy & 2 families with average 5 person/ family & $\begin{array}{l}2 \text { families with average } 5 \text { person per } \\
\text { family }\end{array}$ \\
\hline
\end{tabular}

\section{Methodology}

\subsection{Methods}

The outdoor assessment of urban form is carried out by using the numerical model ENVI -met which simulates the microclimatic changes within urban environments. The relationship between buildings and urban climate can be underst ood through the connection between indoor and outdoor thermal comfort which have shared issues (coupling methodology) (AliToudert and Mayer 2006) (Fig.2).

The methodology has been carried out in the first software cycle, the Computational Fluid Dynamic (CFD) numerical package ENVI-met Beta4 (Bruse 2010) was applied and used to generate fine-tuned meteorological parameters at different heights of a building unit by placing snapshot receptors around the unit to obtain the near walls present day climate conditions for the building. In the Seco nd step, indoor climate conditions were adopted from EPW weather data file measured for a site in Cairo, Egypt. ECOTECT2010 (AutoDesk 2010) is used for solar and weather data analysis to define the numerically simulated day of the typical meteorological year (Fahmy 2010a). ECOTECT is used for its computability with the various used software packages. Both outdoor and indoor simulations performed on a common set of meteorological parameters and mapped to the selected buildings. In the third step, the detailed model built by 3D MAX in separated floors for every detailed model and the resulted thermal maps by ENVI-met and ECOTECT attached into the model. After completion of the 3D modelling, the models will be exported to the X3D format. Finally all the results are gathered on the uCampus platform on which the entire urban neighbourhood is 
built to for inserting both the ENVI-met outdoor mapping and ECOTECT indoor profiling results (Peng et al 2010).

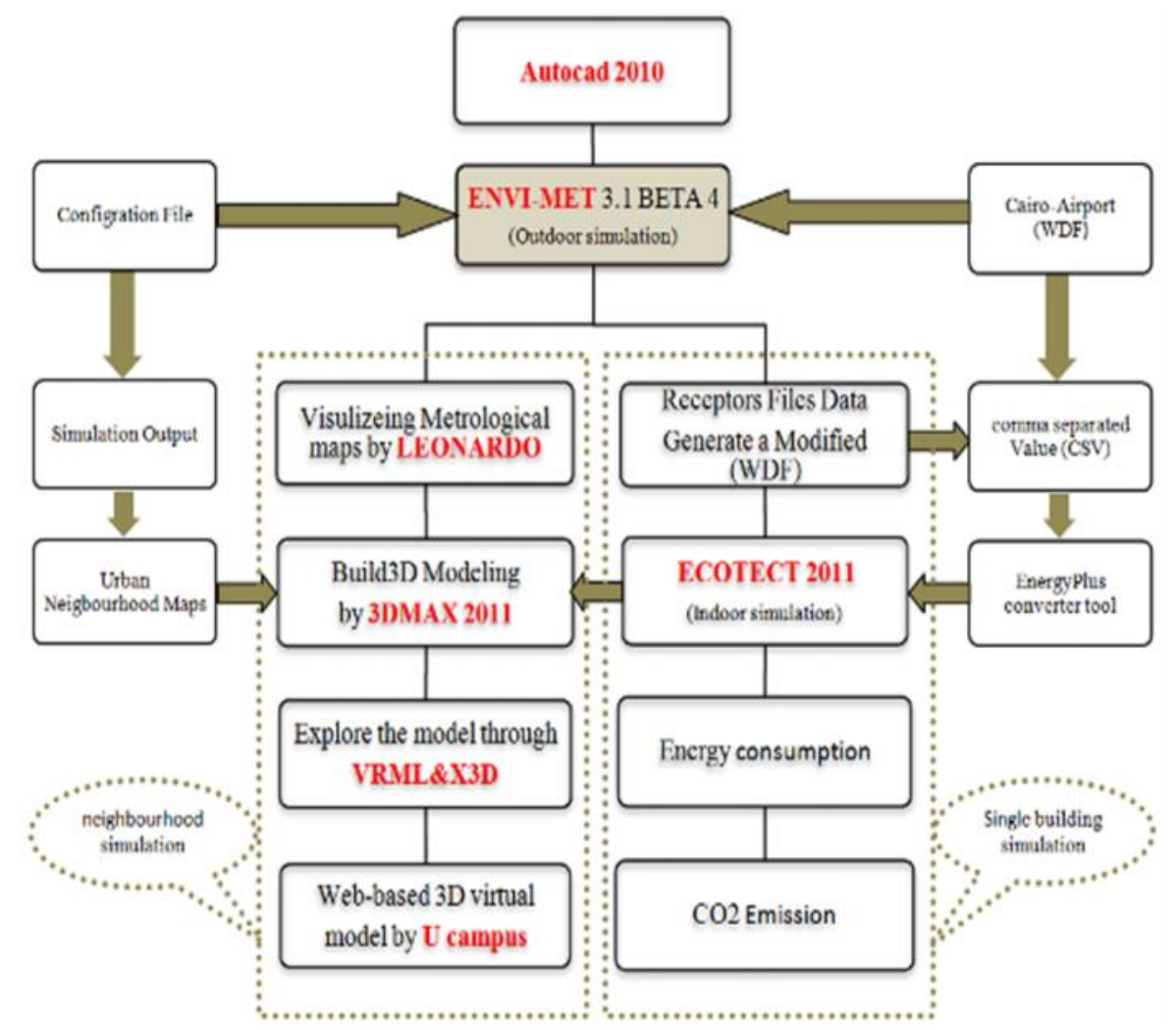

Fig. 2. An outdoor-indoor coupling simulation method based on Weather Data File (WDF).

These two experimental software cycles were applied for the neighbourhood case study to support a comparison among proposed design alternatives. Users are thus able to perceive the combined results via interactive navigation through the 3D virtual urban neighbourhood. These simulations can be used to assess comparative environmental impacts by a neighbourhood urban form.

\subsection{Hypothesis:}

The methodology process will be repeated for the neighbourhood case study in three different conditions which might lead to significant effects on the urban thermal comfort ( Fig. 4).

1. We replace the entire road inside an urban neighbourhood with green pedestrian avenues and we use tunnels for cars under these avenues. That possible to generate a lower temperature and a lower air pressure inside the nei ghbourhood (Fig. 3).

2. The external roads and pavements surrounding the neighborhoods are built in asphalt, Hence, the temperature and the pressure in the areas could conceivably be higher. By raising all residential buildings on columns, the wind density through the urban canyons and surrounding asphalt roads will be increased (Fig. 3).

3. Due to the difference in temperature and air pressure induced from the previous two steps, the redesigned urban neighbourhood will work as a large court yard, leading to 
the differences in the air pressure. Moreover, the wind density and wind speed will increase inside the neigbourhood.

(a)

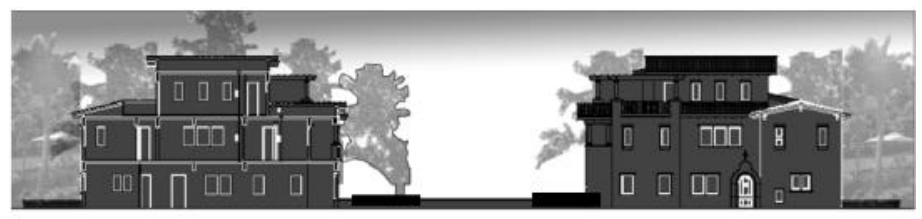

(b)

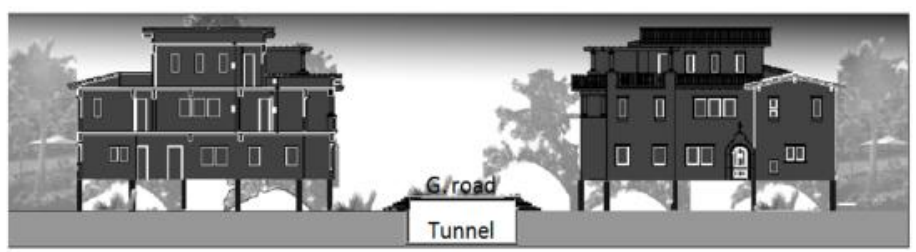

(c)

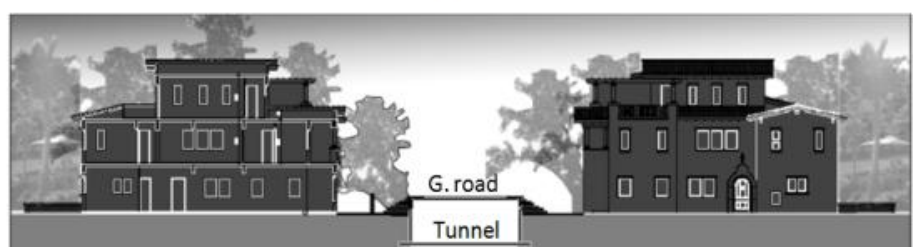

Fig. 3. Residential building of the urban neighbourhood (a) Section of Existing Case (b) Green Road with Raised Ground Floor (c) Section of Green Road.

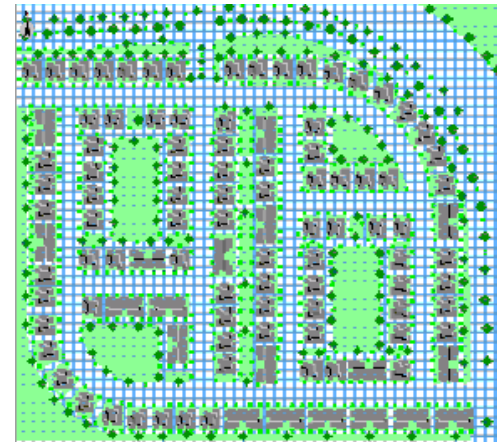

Existing Case.

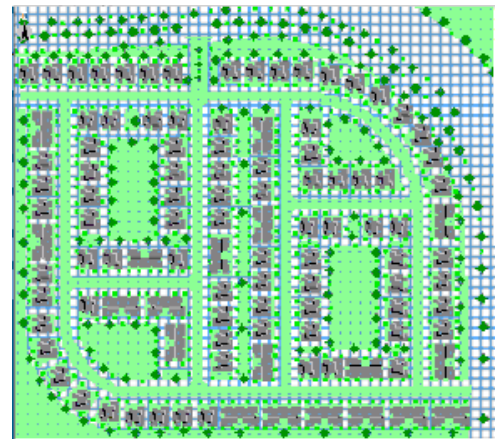

Urban Green Road.

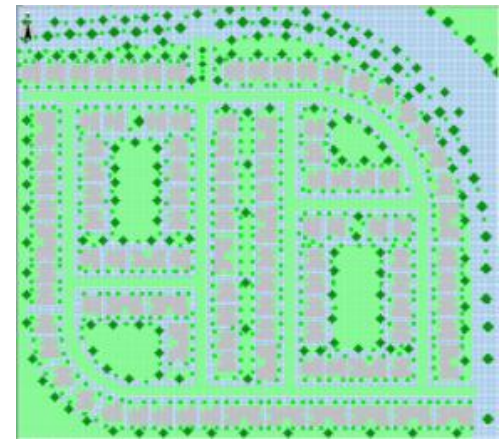

Green Road with Raised G. floor.

Fig .4. Three alternatives of urban neighbourhood redesign drawn in the ENVI-met editor.

This finding, while preliminary, suggests that the combination of passive design tools could provide some support for the conceptual of sustainable urban neighbourhood design. It is therefore likely such connections exist between Outdoor and indoor thermal comfort. It is probable to hypothesis these conditions are more likely to occur in urban neigbourhood.

\section{Results and discussion}

\subsection{Indoor simulation}

Four housing units in different locations of the neighbourhood were selected and the closed thermal zones of every model inside ECOTECT 2011 built. The provided weather data file by 
ENVI-met used into the simulation. Eventually, the detailed m odel built by 3D MAX in separated floors and the resulted thermal maps by ECOTECT attached into the model (Fig.4). However, this simulation will be repeated for the three alternatives by using the different weather data file.
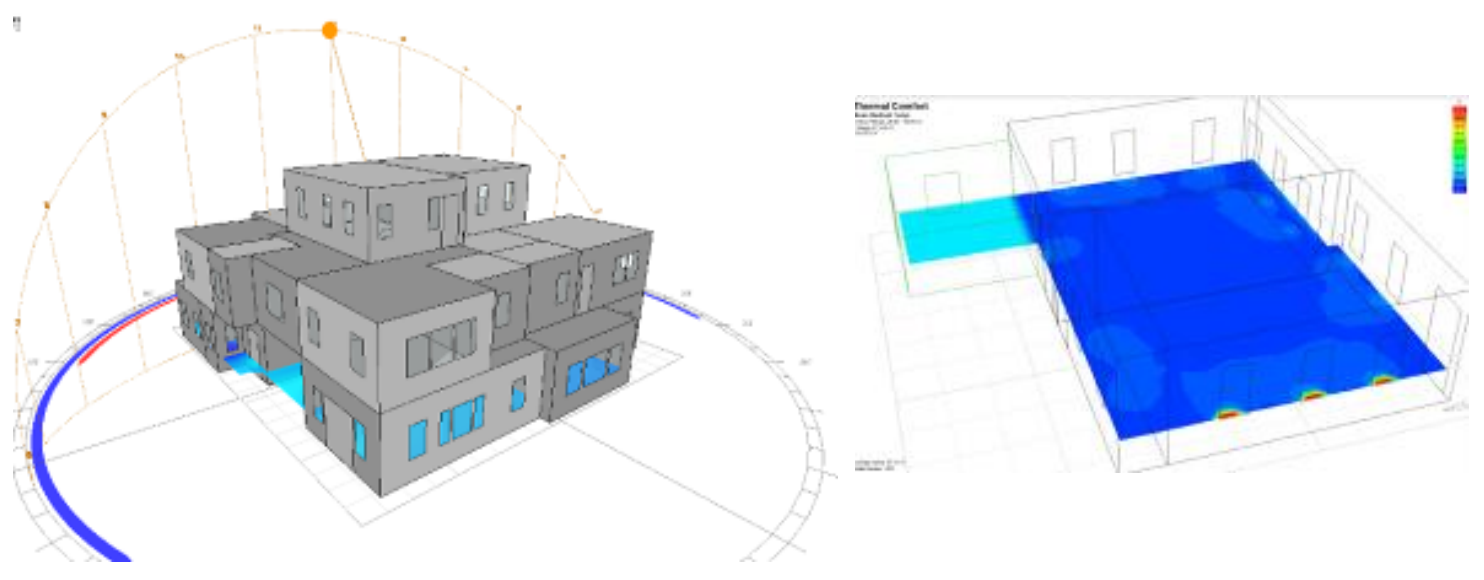

Thermal closed zones of detailed model
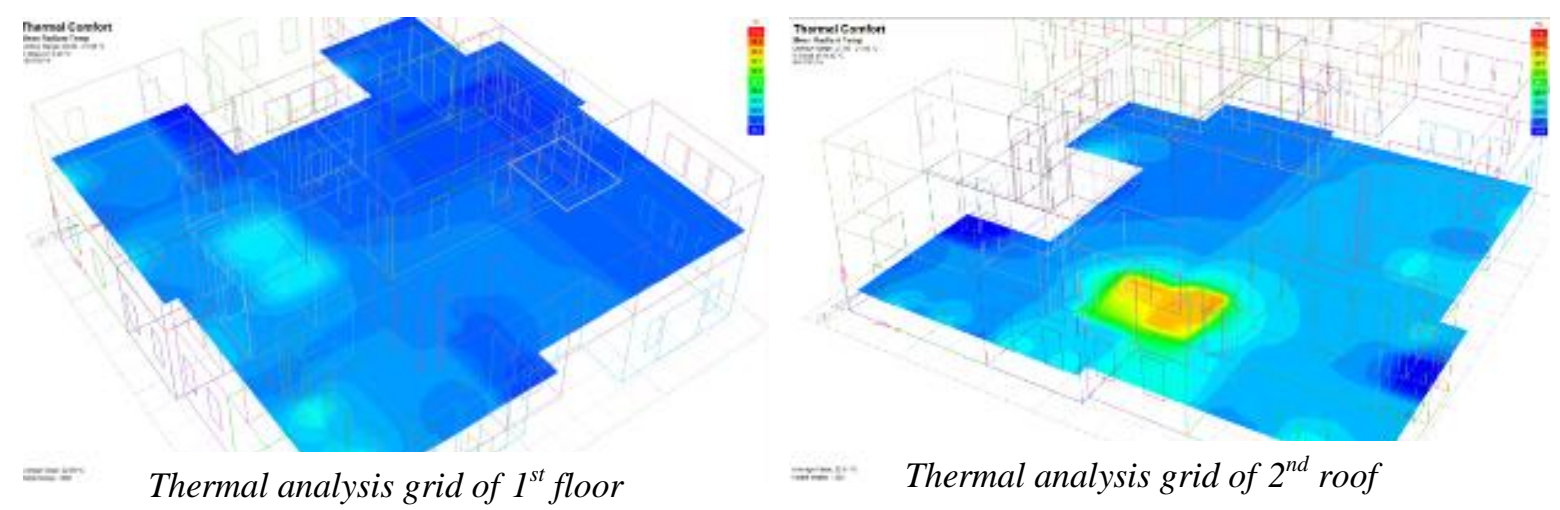

Fig.4. Resulted thermal maps by ECOTECT

\subsection{ENVI-met Outdoor simulation}

The simulation starts to calculate the meteorological factors e.g. (wind speed and direction, air and surface temperature, air humidity, short - wave and long-wave radiation $\mathrm{n}$ fluxes), in addition to the mean radiant temperature which is needed for comfort analyses. The Simulation date was on $7^{\text {th }}$ of June, because it is the typical summer day and started from 10:00 to 1600. After the simulation finished, we had three output: first, the maps which illustrate the different metrological factors by colours, (Table.3); secondly, receptors file which are used to generate an accurate Weather Data File (WDF) instead of the provided one by the United State Department Of Energy (USDOE), which was measured at the C airo Airport, about $30 \mathrm{~km}$ away from the study site; and finally, extracted data for every hour of the simulation, (Table.2). These software cycles (Fig.1) were applied for the neighbourhood case study to support a comparative environmental passive design tools among the three alternatives (Existing case, Green Road and Green Road with Raised G round Floor), (Table2). The comparison among the meteorological data influences the thermal comfort of urban neighbourhood, therefore air temperature, specific humidity, wind speed, relative humidity 
and mean radiant temperature are the parameters which control the urban neig hbourhood thermal comfort. The differences among the three alternatives include the following (Table.2):

- Existing case (alternative 1): There is a higher temperature at outer and inner roads. Wind speed at the outer roads is higher than the inner roads, additionally specific and relative humidity is lower inside the neighbourhood, leading to a lower mean radiant temperature. Eventually all the previous conditions will affect negatively on thermal comfort inside urban neighbourhood, (Table.3).

- Green roads (alternative 2): There is a big difference in temperature at all inner roads. Thermal comfort will improved due to the increase in the wind speed, sp ecific and relative humidity and mean radiant temperature, (Table.3).

- Green roads\& raised ground floor (alternative 3): there is a big difference in temperature not only at inner roads but also at all spatial urban canyons. Furthermore all meteorological factors (e.g. specific humidity, relative humidity, mean radiant temperature) changing to better values which improve thermal comfort of urban neighbourhood.

The results of this simulation was able to identify the significant effects of increase the wind density by generate a difference in temperature and air pressure between outer and inner roads.

Table 2. Comparison among meteorological factors at peak time.

\begin{tabular}{|c|c|c|c|c|c|c|c|c|c|c|c|c|c|c|c|c|c|c|c|}
\hline \multirow[t]{2}{*}{ Param } & eters & \multicolumn{6}{|c|}{$\begin{array}{l}\text { Alternative(1): Existing } \\
\text { Case }\end{array}$} & \multicolumn{12}{|c|}{\begin{tabular}{c|l} 
Alternative(2):Green Road & $\begin{array}{l}\text { Alternative(3):Green-Road } \\
\text { \&Raised Ground Floor }\end{array}$
\end{tabular}} \\
\hline & & 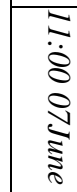 & 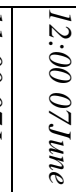 & 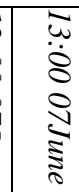 & 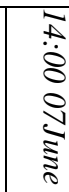 & 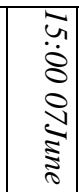 & 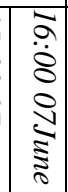 & 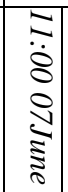 & 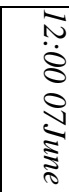 & 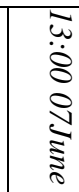 & 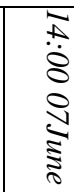 & 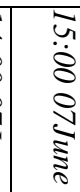 & $\begin{array}{l}\tilde{a} \\
\grave{8} \\
\stackrel{\Xi}{\Xi}\end{array}$ & 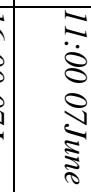 & 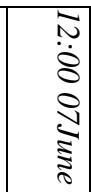 & 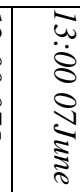 & 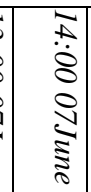 & 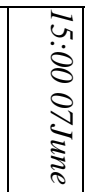 & 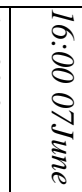 \\
\hline \multirow{3}{*}{$\begin{array}{l}\text { Air } \\
\text { Temp. }\end{array}$} & & $303 k$ & $\begin{array}{l}03 \\
05 K\end{array}$ & $305-$ & $\begin{array}{l}307- \\
308 k\end{array}$ & $308 k$ & $\begin{array}{l}307- \\
308 k\end{array}$ & $303 k$ & $\begin{array}{l}305- \\
307 k\end{array}$ & $6 k$ & $307 k$ & & $\begin{array}{l}07 k \\
308 k\end{array}$ & $303 k$ & & $\overline{06 k}$ & $307 k$ & $\begin{array}{l}307- \\
308 k\end{array}$ & $306-$ \\
\hline & & $303 k$ & $2-$ & $305-$ & $307 k$ & & \begin{tabular}{|l|}
$306-$ \\
$308 k$
\end{tabular} & $303 k$ & & & $\overline{k k}$ & & \begin{tabular}{|l|}
306 \\
$-307 k$ \\
\end{tabular} & $\overrightarrow{3 k}$ & & $4 k$ & $04 k$ & $\begin{array}{l}304- \\
305 k\end{array}$ & 304 \\
\hline & ayon & $n 302 k$ & $4 \mathrm{~K}$ & $\begin{array}{l}304- \\
305 k\end{array}$ & $305 k$ & & $\begin{array}{l}306- \\
307 k\end{array}$ & $302 k$ & & & $305 k$ & & $\begin{array}{l}306- \\
307 k\end{array}$ & $302 k$ & & & 304 & $\begin{array}{l}304- \\
305 k\end{array}$ & \\
\hline \multirow{3}{*}{$\begin{array}{l}\text { Wind } \\
\text { Speed }\end{array}$} & & $\begin{array}{l}2-3 \\
\mathrm{~m} / \mathrm{s}\end{array}$ & & $3 m / s$ & $3 m / s$ & $3 m / s$ & $3 m / s$ & \begin{tabular}{|l}
$2-3$ \\
$\mathrm{~m} / \mathrm{s}$
\end{tabular} & $3 m / s$ & $2 / s$ & $3 m / s$ & $n / s$ & $3 m / s$ & $\begin{array}{l}2 m / s \\
3 m / s\end{array}$ & & $n / s$ & $3 m / s$ & $3 m / s$ & $3 m$ \\
\hline & & $\begin{array}{l}1-3 \\
\mathrm{~m} / \mathrm{s}\end{array}$ & & $\begin{array}{l}1-3 \\
\mathrm{~m} / \mathrm{s}\end{array}$ & $\begin{array}{c}1-3 \\
\mathrm{~m} / \mathrm{s}\end{array}$ & $\mathrm{m} / \mathrm{s}$ & $\begin{array}{l}2-3 \\
\mathrm{~m} / \mathrm{s}\end{array}$ & $\begin{array}{l}1-2 \\
\mathrm{~m} / \mathrm{s}\end{array}$ & & & & & & & & & $\mathrm{m} / \mathrm{s}$ & $\mathrm{m} / \mathrm{s}$ & $\mathrm{m} / \mathrm{s}$ \\
\hline & $n$ & $\begin{array}{l}0.5-3 \\
\mathrm{~m} / \mathrm{s}\end{array}$ & & $\begin{array}{l}2-3 \\
\mathrm{~m} / \mathrm{s}\end{array}$ & $\begin{array}{l}2-3 \\
\mathrm{~m} / \mathrm{s}\end{array}$ & \begin{tabular}{|l|}
$2-3$ \\
$\mathrm{~m} / \mathrm{s}$
\end{tabular} & $\begin{array}{l}2-3 \\
\mathrm{~m} / \mathrm{s}\end{array}$ & \begin{tabular}{|l|}
$1-3$ \\
$\mathrm{~m} / \mathrm{s}$
\end{tabular} & & & $\begin{array}{l}2-3 \\
\mathrm{~m} / \mathrm{s}\end{array}$ & & $\begin{array}{l}2-3 \\
\mathrm{~m} / \mathrm{s}\end{array}$ & & & & $\begin{array}{l}2-3 \\
\mathrm{~m} / \mathrm{s}\end{array}$ & & \\
\hline \multirow[t]{3}{*}{$\begin{array}{l}\text { Specific } \\
\text { Humidity }\end{array}$} & \begin{tabular}{|l} 
Outer \\
roads
\end{tabular} & \begin{tabular}{|l|}
$13-16$ \\
$\mathrm{~g} / \mathrm{kg}$
\end{tabular} & $\begin{array}{l}14-15 \\
\mathrm{~g} / \mathrm{kg}\end{array}$ & $\begin{array}{l}13-14 \\
\mathrm{~g} / \mathrm{kg}\end{array}$ & $\begin{array}{l}12-13 \\
\mathrm{~g} / \mathrm{kg}\end{array}$ & \begin{tabular}{|l|}
$13 g / k$ \\
$g$
\end{tabular} & $\begin{array}{l}12 g / \\
\mathrm{kg}\end{array}$ & \begin{tabular}{l|}
$14-$ \\
16 \\
$g / k g$
\end{tabular} & $\begin{array}{l}14-15 \\
g / k g\end{array}$ & $\begin{array}{l}3- \\
14 \mathrm{~g} / \mathrm{kg}\end{array}$ & $13 \mathrm{~g} / \mathrm{kg}$ & $g / 12 \mathrm{~g} / \mathrm{kg}$ & $12 g / \mathrm{kg}$ & $\begin{array}{l}\text { I4-16 } \\
\mathrm{g} / \mathrm{kg}\end{array}$ & $\begin{array}{l}14-15 \\
\mathrm{~g} / \mathrm{kg}\end{array}$ & $\begin{array}{l}13-14 \\
\mathrm{~g} / \mathrm{kg}\end{array}$ & $13 g$ & $12 g$ & $12 g$ \\
\hline & $\begin{array}{l}e r \\
\text { ids }\end{array}$ & $g / k g$ & $\begin{array}{l}13-14 \\
\mathrm{~g} / \mathrm{kg}\end{array}$ & $\begin{array}{l}13-14 \\
\mathrm{~g} / \mathrm{kg}\end{array}$ & $\begin{array}{l}13 \\
\mathrm{~g} / \mathrm{kg}\end{array}$ & $\begin{array}{l}13 \\
\mathrm{~g} / \mathrm{kg}\end{array}$ & \begin{tabular}{|l|}
12 \\
$\mathrm{~g} / \mathrm{kg}$
\end{tabular} & \begin{tabular}{|l|}
$13-$ \\
$15 g /$
\end{tabular} & $\begin{array}{l}14-15 \\
g / k g\end{array}$ & $g / k g$ & $13 g$ & $g$ & $\begin{array}{l}12- \\
13 \mathrm{~g} / \mathrm{kg}\end{array}$ & \begin{tabular}{|l}
$13-14$ \\
$g \mathrm{~g} / \mathrm{kg}$
\end{tabular} & $g$ & $\overrightarrow{\beta g}$ & g|13g & $12 \mathrm{~g}$ & $12 \mathrm{~g}$ \\
\hline & & $\begin{array}{l}13-15 \\
\mathrm{~g} / \mathrm{kg}\end{array}$ & $\begin{array}{l}14-15 \\
\mathrm{~g} / \mathrm{kg}\end{array}$ & $\begin{array}{l}13-14 \\
\mathrm{~g} / \mathrm{kg}\end{array}$ & $\begin{array}{l}13 \\
\mathrm{~g} / \mathrm{kg}\end{array}$ & $\begin{array}{l}13 \\
\mathrm{~g} / \mathrm{kg}\end{array}$ & \begin{tabular}{|l|}
$12 g /$ \\
$\mathrm{kg}$
\end{tabular} & \begin{tabular}{|l|}
$14-$ \\
$15 \mathrm{~g}$
\end{tabular} & $14 \mathrm{~g} / \mathrm{kg}$ & $14 g / k$ & $13 \mathrm{~g} / \mathrm{kg}$ & $g \mid 12 \mathrm{~g} / \mathrm{kg}$ & $12 \mathrm{~g} / \mathrm{kg}$ & $\begin{array}{l}13-14 \\
\mathrm{~g} / \mathrm{kg}\end{array}$ & kg & $13 \mathrm{~g} / \mathrm{kg}$ & $g \mid J g / k g$ & $12 \mathrm{~g} / \mathrm{kg}$ & $2 g$ \\
\hline \multirow[t]{3}{*}{\begin{tabular}{|l|} 
Relative \\
Humidity
\end{tabular}} & \begin{tabular}{|l|} 
outer \\
roads
\end{tabular} & $\begin{array}{l}53-62 \\
\%\end{array}$ & $\begin{array}{l}49- \\
55 \%\end{array}$ & $\begin{array}{l}43- \\
46 \%\end{array}$ & $\begin{array}{l}39- \\
40 \%\end{array}$ & $37 \%$ & $37 \%$ & \begin{tabular}{|l|}
$56-$ \\
$62 \%$
\end{tabular} & $\begin{array}{l}49- \\
54 \%\end{array}$ & & $51 \%$ & $-38 \%$ & \begin{tabular}{|l|}
37 \\
$-38 \%$ \\
\end{tabular} & & & & $\begin{array}{l}40 \\
-41 \% \\
\end{array}$ & $\begin{array}{l}37 \\
-38 \% \\
\end{array}$ & $\begin{array}{l}37 \\
-38 \%\end{array}$ \\
\hline & \begin{tabular}{|l|}
$\begin{array}{l}\text { Inner } \\
\text { roads }\end{array}$ \\
\end{tabular} & \begin{tabular}{|l|}
$53-59$ \\
$\%$
\end{tabular} & $\begin{array}{l}48- \\
52 \% \\
\end{array}$ & $\begin{array}{l}44- \\
46 \% \\
\end{array}$ & $\begin{array}{l}40- \\
41 \%\end{array}$ & $39 \%$ & $38 \%$ & \begin{tabular}{|l|}
$56-$ \\
$59 \%$ \\
\end{tabular} & $53 \%$ & $\begin{array}{l}46- \\
47 \%\end{array}$ & $\begin{array}{l}42- \\
43 \%\end{array}$ & $\begin{array}{l}37- \\
39 \% \\
\end{array}$ & $\begin{array}{l}37- \\
39 \% \\
\end{array}$ & $59 \%$ & $53 \%$ & $47 \%$ & $43 \%$ & $39 \%$ & $39 \%$ \\
\hline & canvon & $53-$ & $52-$ & $\begin{array}{l}47- \\
48 \% \\
\end{array}$ & $\begin{array}{l}42- \\
43 \%\end{array}$ & $\begin{array}{l}39- \\
40 \% \\
\end{array}$ & $\begin{array}{l}39- \\
40 \% \\
\end{array}$ & \begin{tabular}{|l|}
$56-$ \\
$59 \%$
\end{tabular} & & & $42-$ & & 39- & & & & & & \\
\hline \multirow{3}{*}{\begin{tabular}{|l} 
Mean \\
Radiant \\
Temp.
\end{tabular}} & & $334 k$ & $332 k$ & $339 k$ & $348 k$ & $350 k$ & $350 k$ & $334 k$ & $332 k$ & $339 k$ & $348 k$ & $350 k$ & $350 k$ & $334 k$ & $332 k$ & $339 k$ & $348 k$ & $350 k$ & 350 \\
\hline & & $334 k$ & $32 k$ & $339 k$ & $348 k$ & $350 k$ & $55 k$ & $334 k$ & $332 k$ & $39 k$ & $348 k$ & $0 k$ & $\overline{55 k}$ & $\overline{34 k}$ & $332 k$ & $39 k$ & $48 k$ & $50 k$ & $55 t$ \\
\hline & canyo & $m$ & $32 k$ & $39 k$ & $348 k$ & $50 k$ & $50 k$ & $334 k$ & एכ, & 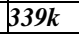 & $348 k$ & $50 K$ & Jo & $04 \pi$ & $32 t$ & $39 \%$ & 40 & $350 k$ & t \\
\hline
\end{tabular}


Proceedings of the $\mathbf{9}^{\text {th }}$ ICCAE-9 Conference, 29-31 May, 2012

Table 3. Comparison among Meteorological Urban Neighbourhood Maps.

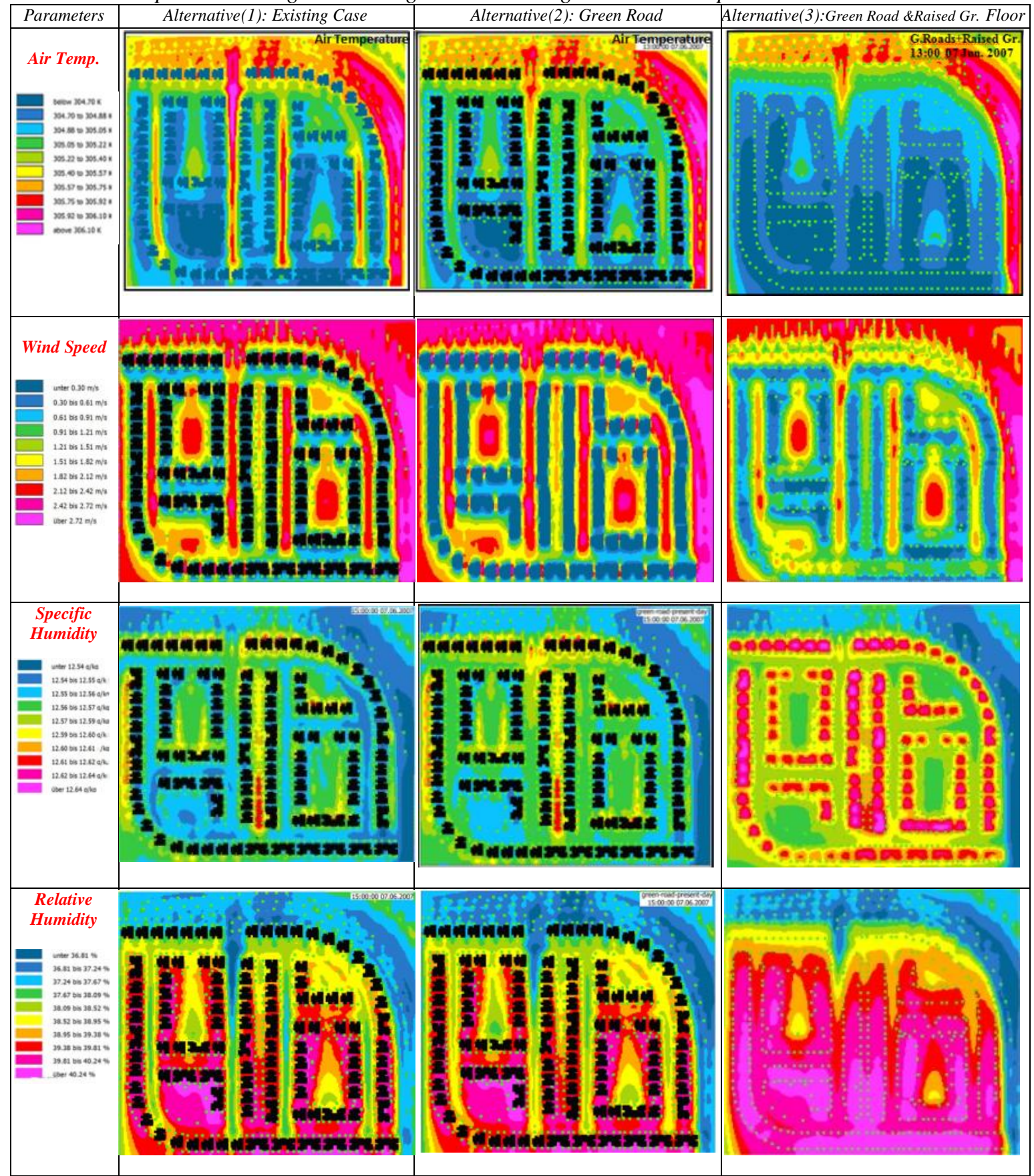




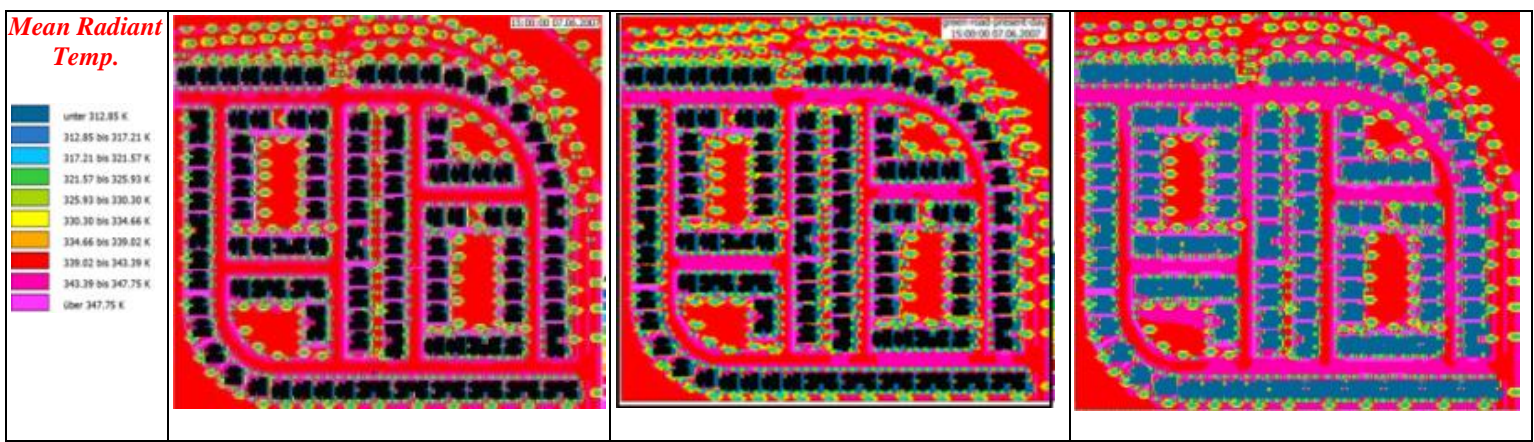

\subsection{Coupling outdoor and indoor}

As ENVI-met does not have the capability to simulate indoor climate, ECOTECT 2011 was used to simulate indoor climate based on WDF generated by ENVI -met. The Explanation of these results by visualizing the coupled outdoor-indoor climate conditions is significant.

Moreover, another visualization scheme and 3D thematic models for the coupled outdoorindoor conditions can also be generated and hence an implication and a measure for sustainability can take place for future urban development by using Weather Data File for future climate (Fig.4).
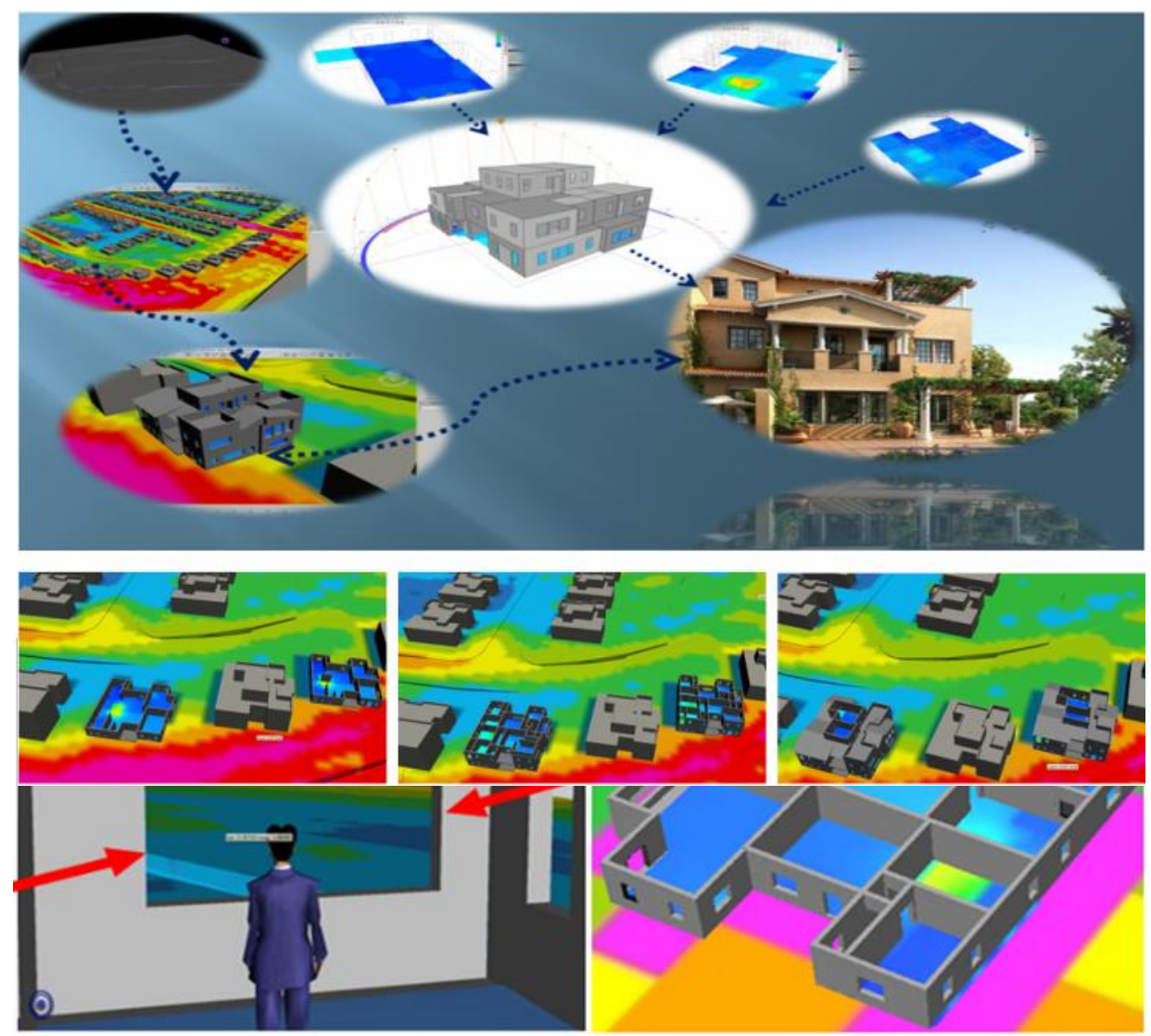

Fig.4.

Bring outdoor and indoor simulation together by $3 D$ virtual model 
The user able to have an integrated image between outdoor and outdoor environment and walk through the virtual model make a sense for different meteorological data. Moreover architects and planners are enabled to realize the relation between outdoor and indoor conditions and take sustainable design into consideration. By this methodology the comparison between different design alternatives is available furthermore measuring therm al comfort efficiency of urban neighbourhood (Fig.5).
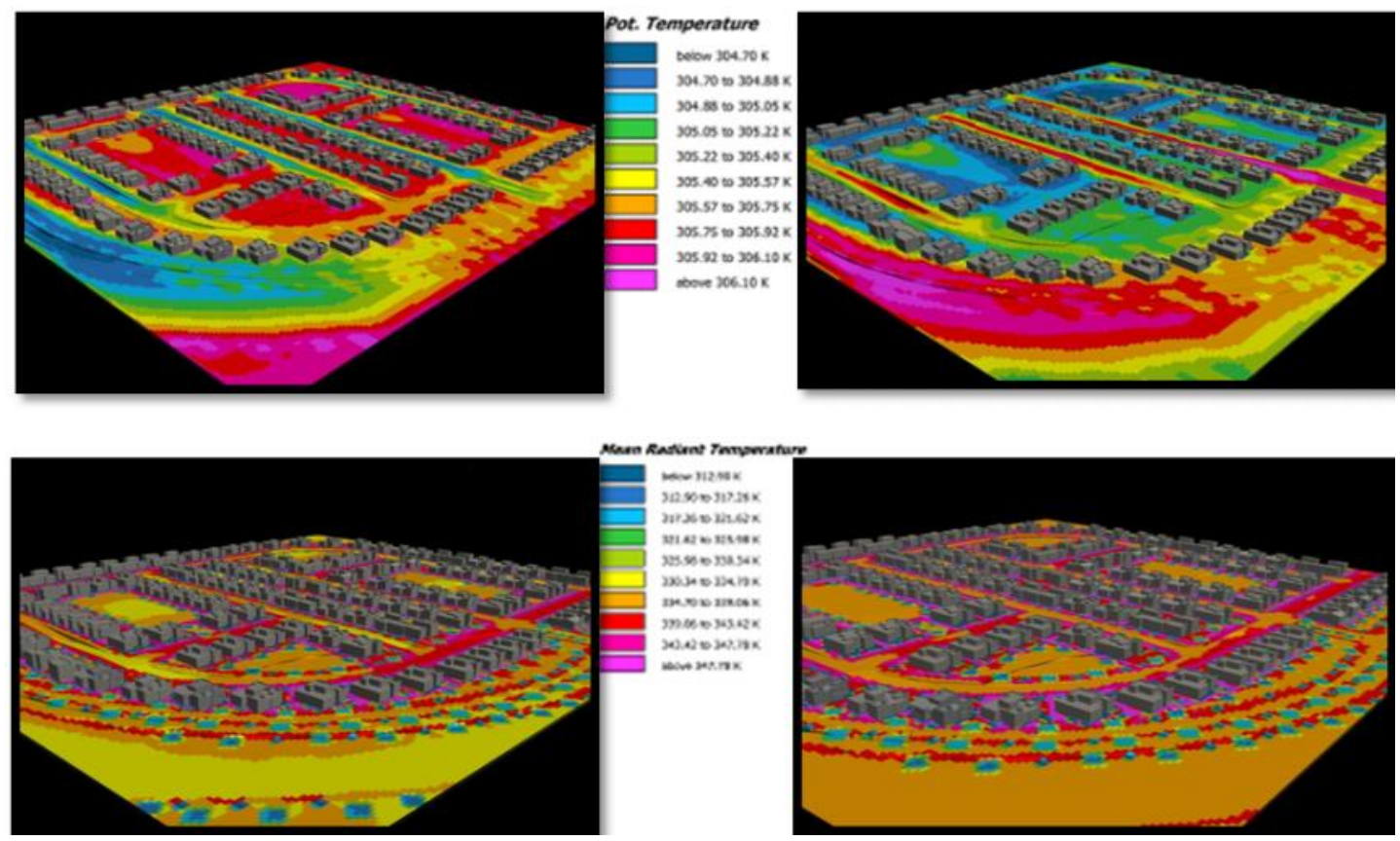

Fig.5. Bring outdoor and indoor simulation together on an X3D based visualization platform.

\section{Conclusion and Further research}

This study draws attention to the prevailing wind and its effeteness on urban neighbourhood thermal comfort. Therefore further research has to be more clearly understood that the wind direction and density are important issues to increase pedestrian's thermal comfort inside the urban neighbourhood. Future research should be done to investigate the previous methodology to focus on the interaction between outdoor - indoor thermal comfort. However these results were very encouraging to use the passive design tools specifically to support urban neighbourhood design, e.g. the wind direction is blocked by some buildings so raising ground floor over columns improves the spatial distribution of wind velocity. Additionally, the comparison between present and future meteorological data needs to support coupling methodology to simplify the comparison between present and future meteorological data, which supported global climate change conscious urban neighbourhood design. Furthermore, using features provided by visualization of meteorological data. Users are thus able to perceive the combined results via interactive navigation through the $3 \mathrm{D}$ virtual urban neighbourhood. 


\section{References}

[1] Ali-Toudert, F., M. Djenane, et al. (2005). "Outdoor thermal comfort in the old desert city of Beni-Isguen, Algeria." Climate Research 28(3): 243-256.

[2] Ali-Toudert, F. and H. Mayer (2006). "Numerical study on the effects of aspect ratio and orientation of an urban street canyon on outdoor thermal comfort in hot and dry climate." Building and Environment 41(2): 94-108.

[3] Ali-Toudert, F. and H. Mayer (2007b). "Effects of asymmetry, galleries, overhanging fac,ades and vegetation on thermal comfort in urban street canyons." Solar Energy 81(6): 742-754.

[4] Asawa, T., A. Hoyano, et al. (2008). "Thermal design tool for outdoor spac es based on heat balance simulation using a 3D-CAD system." Building and Environment 43(12): 2112-2123.

[5] AutoDesk. (2010). "ECOTECT2010, [Online], Available at: http://www.autodesk.co.uk/adsk/servlet/mform?validate=no\&siteID=452932\&id=142 05163. Accessed 19/4/2010."

[6] Bruse, M. (2010). "ENVI-met V3.1, a microscale urban climate model, [Online], Available: www.envi-met.com. Accessed 18/10/2010."

[7] Eliasson, I. (2000). "The use of climate knowledge in urban planning ." Landscape and urban planning 48(1-2): 31-44.

[8] Fahmy, M. (2010a). Interactive urban form design of local climate scale in hot semi arid zone. Sheffield, University of S heffield. PhD: 175.

[9] Fahmy, M. and S. Sharples (2008b). "The need for an urban climatology applied design model, [Online]. Available at: http://www.urban-climate.org/IAUC028.pdf." The online newsletter of the International Assocciation for Urban Climatology 2008(28): 15-16.

[10] Oke, T. R. (1984). "Towards a prescription for the greater use of climatic principles in settlement planning." Energy and Buildings 7(1): 1-10.

[11] Oke, T. R. (2006). "Towards better scientific communication in urban climate." Theoretical and Applied Climatology 84(1-3): 179-190.

[12] Peng et al (2010). "Developing a Web-Based 3D Visualisation Modelling Platform to Support Innovative Planning and Design of Learning Spaces: A Case Study of the University of Sheffield Campus". 10th International Conference on Design \& Decision Support Systems in Architecture and Urban Planning Eindhoven, The Netherlands.

[13] Ratti, C., D. Raydan, et al. (2003). "Building form and environmental performance: archetypes, analysis and an arid climate." Energy and Buildings 35(1): 49-59. 